\title{
ARTICLE
}

\section{The Legitimacy of Dam Development in International Watercourses: A Case Study of the Harirud River Basin}

\author{
Mohsen Nagheeby, ${ }^{*}$ Mehdi Piri D.** and Michael Faure***
}

\begin{abstract}
This article examines the international legitimacy of unilateral dam development in an international watercourse from the perspective of international water law. Drawing upon technical analysis over the Harirud River Basin, the article discusses probable negative impacts of unilateral dam development in Afghanistan on downstream Iran and Turkmenistan. Competing claims are analyzed to assess emerging transboundary damage under customary international water law. Applying these insights to the case study, this article explores how legal norms and principles can contribute to transboundary water cooperation. It investigates how equitable and reasonable utilization, as required by the United Nations Watercourse Convention, could be reached and whether current activities are in conformity with international norms. Based on this analysis and in the light of international customary law, the article questions the compatibility of unilateral control and capture of water resources in Afghanistan, particularly through the Salma Dam, with 'equitable and reasonable utilization' and 'no significant harm' rules. The article also argues that building the Salma Dam results in significant transboundary harm to downstream states. Hence, such harm could be considered as significant transboundary damage. Conclusions point to an understanding of water law as a form of institutional guidance in order to provide a transparent setting for transboundary water cooperation among riparian states.
\end{abstract}

Keywords: Transboundary damage, International water law, Unilateral dam development, Harirud, Afghanistan

* School of Law, Northumbria University at Newcastle (United Kingdom).

Email: mohsen.nagheeby@northumbria.ac.uk.

** Faculty of Law and Political Science, University of Tehran (Iran).

Email: mehdi.piri@ut.ac.ir.

$\because *$ Faculty of Law, Maastricht University (The Netherlands).

Email: michael.faure@maastrichtuniversity.nl.

The authors are grateful to three anonymous referees for useful comments on an earlier draft of this article. 


\section{INTRODUCTION}

One of the key challenges for the $21^{\text {st }}$ century is the sharing of international water resources. The global community is concerned mostly by the lack of a holistic cooperative legal framework for most of the world's 263 transboundary river basins. ${ }^{1}$ An important aspect of this challenge regards the scope for how international law resolves conflicts and provides a sustainable solution related to transboundary rivers. ${ }^{2}$ Building on the rich literature on international water law, this article analyzes the legitimacy of dam building in relation to the law of international watercourses. ${ }^{3}$ The contribution of international water law is investigated by examining the specific case of the Harirud/ Tejen River Basin (hereafter referred to as the Harirud Basin), which is an international water basin shared between Afghanistan, Iran, and Turkmenistan.

Water resources have crucially contributed to the livelihood of the people in the Harirud Basin. ${ }^{4}$ A growing population, economic development, the impacts of climate change, along with poor water governance, have placed enormous pressure on the water resources of the Harirud River. ${ }^{5}$ This article will therefore argue that all riparian states (upstream Afghanistan, downstream Iran and Turkmenistan) have focused mainly on dam development to harness the water to relieve this pressure without respecting the water rights in the basin. ${ }^{6}$ In 2016, Afghanistan, as the upstream latedeveloping country, officially opened the Salma Dam on the upper reaches of the Harirud River. ${ }^{7}$ It is said that this dam will cut down the water flow of the river to Iran and Turkmenistan by $73 \% .^{8}$ However, in 2004, Iran and Turkmenistan had already constructed a common dam, the Doosti Dam (doosti meaning 'friendship' in

1 A.T. Wolf, Atlas of International Freshwater Agreements, Vol. 4 (UNEP/Earthprint, 2002).

2 However, 'because water is an inter-disciplinary resource, international legal norms cannot by themselves provide resolution to disputes over international watercourses. Equally important is the fact that there can be no resolution of water disputes without international legal norms on international watercourses': S.M.A. Salman \& L. Boisson de Chazournes, International Watercourses: Enhancing Cooperation and Managing Conflict: Proceedings of a World Bank Seminar (World Bank, 1998), p. 119.

3 Yihdego and Rieu-Clarke explore legitimacy and distributive justice within the context of fairness over international watercourses: Z. Yihdego \& A. Rieu-Clarke, 'An Exploration of Fairness in International Law through the Blue Nile and GERD' (2016) 41(4) Water International, pp. 528-49. Borrowing from Thomas Franck (1995), they describe legitimacy as 'procedural fairness' and associate distributive justice with substantive principles of international water law: see, e.g., T.M. Franck, Fairness in International Law and Institutions (Clarendon Press, 1995).

4 See, e.g., United Nations Economic Commission for Europe (UNECE), 'Second Assessment of Transboundary Rivers, Lakes and Groundwaters', Aug. 2011, available at: https:/www.unece.org/ env/water/second_assessment.html.

5 Ibid., pp. 129-30.

6 See, e.g., EastWest Institute, 'Enhancing Security in Afghanistan and Central Asia through Regional Cooperation on Water', Amu Darya Basin Consultation Report, 1 May 2011, available at: https://www.eastwest.ngo/idea/enhancing-security-afghanistan-and-central-asia-through-regional-cooperationwater.

7 See, e.g., 'Modi and Ghani Opened the Salma Dam', BBC Farsi, 4 June 2016, available at: http://www.bbc.com/persian/afghanistan/2016/06/160604_k05_slama_dam_(in Farsi).

8 For general discourses on the impacts arising from the Salma Dam and concerns of downstream countries, see S. Peterson, 'Why a Dam in Afghanistan Might Set Back Peace', The Christian Science Monitor, 30 July 2013, available at: http://www.csmonitor.com/World/Asia-South-Central/2013/0730/Why-adam-in-Afghanistan-might-set-back-peace. 
the Persian language). These unilateral and bilateral dam constructions on the Harirud Basin, without any trilateral cooperation between Afghanistan, Iran and Turkmenistan, may well become a source of disputes in the region.

Afghanistan is one of the most geopolitically important areas in the world. ${ }^{9}$ The 'great game'10 between the world's superpowers has created the current structure of Afghanistan with its related international law problems. The regional countries have become embroiled in competition over 'influence, power, hegemony and profits' 11 and competition between India and Pakistan is rampant in Afghanistan. ${ }^{12}$ Continuing the political approach of superpowers, these states have been playing out their rivalries in Afghanistan either by financial investment or through political interference. ${ }^{13}$ In 2002, India promised USD 750 million in aid and Pakistan promised USD 150 million. ${ }^{14}$ In particular, the Salma Dam, the case studied in this contribution, is funded by a USD 200 million-plus grant from the Indian government. ${ }^{15}$ It has been argued that by planning to construct 62 dams in Afghanistan, India is furthering its own hegemonic ambitions against Pakistan. ${ }^{16}$ The Asian Development Bank (ADB) and the World Bank, along with other international institutions, are also involved, technically or financially, in development plans for the basin inside Afghanistan. ${ }^{17}$ It is therefore interesting to consider how legal rules have played out in this first case study of unilateral dam development, and to investigate how the concept of 'equitable and reasonable utilization' has been implemented in a politically charged environment. It is also interesting to mention that many international organizations have taken up

9 For a discussion of Afghanistan and surrounding politics, see P. Hopkirk, The Great Game: The Struggle for Empire in Central Asia (Kodansha Globe, 1992). For more information see also D.L. Smith, 'Central Asia: A New Great Game?' (1996) 23(3) Asian Affairs: An American Review, pp. 147-75; see also S. Tanner \& R. Todd, Afghanistan: A Military History from Alexander the Great to the Fall of the Taliban (Blackstone Audio Incorporated, 2012). For an extensive discussion on 'the new great game', see L. Kleveman, The New Great Game: Blood and Oil in Central Asia (Grove Press, 2004).

10 The 'great game' is a term which referred originally to the strategic and rivalry conflicts between the Russian and British Empires in the $19^{\text {th }}$ century to control the geopolitical land of Afghanistan in Central Asia.

11 For general discussion of how and why regional states engage in Afghanistan, see, e.g., Economist Staff, 'The Great Game Revisited: India and Pakistan Are Playing out Their Rivalries in Afghanistan', The Economist, 22 Mar. 2007, available at: http://www.economist.com/node/8896853. For an extensive discussion of Afghanistan's dam development and geopolitical characteristics, see M. Nagheeby \& J. Warner, 'The Geopolitical Overlay of the Hydropolitics of the Harirud River Basin' (2018) 18(6) International Environmental Agreements: Politics, Law and Economics, pp. 839-60.

12 H.V. Pant, 'India in Afghanistan: A Test Case for a Rising Power' (2010) 18(2) Contemporary South Asia, pp. 133-53.

13 Ibid., pp. 148-50.

14 Pant, n. 12 above.

15 See, e.g., 'Salma Dam to be Completed in 9 Months: Afghan Ministry of Energy and Water', Wadsam News, 7 Sept. 2013, available at: http://www.wadsam.com/salma-dam-to-be-completed-in-9-monthsafghan-ministry-of-energy-and-water-232.

16 See, e.g., Economist Staff, n. 11 above.

17 See Asian Development Bank (ADB), 'Western Basins Water Resources Management and Irrigated Agriculture Development Project', Technical Assistance Reports, Oct. 2004, p. 3. For more information, see also M.A. Clemens \& M. Kremer, 'The New Role for the World Bank' (2016) 30(1) Journal of Economic Perspectives, pp. 53-76, at 60; and WHO, UNICEF, UNFPA, World Bank Group and the UN Population Division, 'Trends in Maternal Mortality: 1990-2015', Nov. 2015, available at: https://www.who.int/reproductivehealth/publications/monitoring/maternal-mortality-2015/en. 
commitments in the region. This leads to the question of the responsibility of those international organizations in that:

while ADB and its co-financing partners are not directly involved in developing the Salma Dam, the association and possible interdependence of activities within the ADB Project and development of the dam pose reputational risks to $\mathrm{ADB}$ and its co-financing partners if the dam is not developed in accordance with the best international practices and ADB safeguard policies. ${ }^{18}$

This contribution will argue that the dam development in the Harirud Basin challenges the principles of 'equitable and reasonable utilization' along with the 'no-harm obligation', the main concepts indicated in Articles 5 and 7 of the 1997 UN Convention on the Law of the Non-navigational Uses of International Watercourses (referred to also as the UN Watercourses Convention (UNWC)). ${ }^{19}$ The riparian states of the Harirud River all claim to respect the applicable international conventions as well as customary international water law. This therefore raises the question of how to qualify the unilateral development of the dam under customary international law. The challenge is especially interesting since the dam in question was constructed by Afghanistan, which has the lowest development index of the three riparian states. Afghanistan therefore claims that it needs the dam in order to raise its development level, which raises the question of whether this argument can justify jeopardizing the interests of the downstream states. It is therefore permissible to raise a question of legitimacy in the manner in which it is here discussed.

A large dam changes the flow of a river. Hence, the construction of a dam in a transboundary river by an upstream state often leads to conflicts with downstream states. The case of the Salma Dam is particularly interesting, given that it is constructed in a region of high tension and has been promoted as a tool to foster economic development in Afghanistan and help to lift the population out of poverty. This article will make use of an earlier study which analyzed the impacts of the development of the dam and the specific hydrological consequences for the basin. ${ }^{20}$ The case study in this article may also be used as an analytical example for similar dams like the Turkish Ilisu Dam on the Tigris and the Grand Ethiopian Renaissance Dam on the Blue Nile River.

The study considers primarily the role of Iran and Afghanistan and does not pay specific attention to the situation of Turkmenistan. To an important extent Turkmenistan has the same status as Iran as a downstream user of the river. Unfortunately, data for the situation of Turkmenistan is not available and the transboundary water interactions

18 ADB, ibid.

19 New York, NY (United States (US)), 21 May 1997, in force 17 Aug. 2014, available at: http://legal.un.org/ilc/texts/instruments/english/conventions/8_3_1997.pdf. This article discusses the UNWC but not the UNECE Convention on the Protection and Use of Transboundary Watercourses and International Lakes (Helsinki (Finland), 17 Mar. 1992, in force 6 Oct. 1996, available at: https://www.unece.org/fileadmin/DAM/env/water/pdf/watercon.pdf) because, although neither convention is binding upon the riparian states of the Harirud River, the former to a large extent reflects customary international water law (see $\mathrm{n} .78$ below).

20 M. Nagheeby, Analysis of the Hydro-political Impacts of Dam Development in Transboundary River Basins: A Case Study of the Harirud River Basin (MSc dissertation, UNESCO-IHE, 2014), available at: https://www.researchgate.net/publication/328791212_Analysis_of_the_Hydro-Political_Impacts_ of_Dam_Development_in_Transboundary_River_Basins_A_Case_Study_of_the_Harirud_River_Basin. 
between Iran and Afghanistan are more visible. The article first provides some background facts concerning the Harirud River in Section 2. Section 3 analyzes the legitimacy of the construction of a dam in a shared watercourse under international law. The possible negative consequences of the dam's construction are outlined in Section 4. Section 5 then examines the negative consequences of the construction in the light of the principles of international water law, before Section 6 concludes.

\section{BACKGROUND TO THE HARIRUD RIVER CONFLICT}

\subsection{Geographical and Socio-economic Background}

The 1,124 kilometres $(\mathrm{km})$ long Harirud River originates in the high mountains of Afghanistan over 3,000 metres above sea level. The Harirud River, which has a total drainage area of approximately $112,000 \mathrm{~km}^{2}$, flows from the Koh-i-Baba Mountains $(250 \mathrm{~km}$ west of Kabul) to the west. Around $70 \mathrm{~km}$ east of Herat, the Kabgan (Kawgan) River, the major tributary of the Harirud River in Afghanistan which flows almost parallel to it, also joins the Harirud River. Then, continuing to the west through the city of Herat, it turns northwards to reach the Iranian part and forms approximately $160 \mathrm{~km}$ of the political border between Afghanistan and Iran. Later, by joining the Kashafrud River, it shapes around $170 \mathrm{~km}$ of the political border between Iran and Turkmenistan (this part of the river which forms the political border between Iran and Turkmenistan is officially known as the Tejen River), and finally it irrigates the Karakum desert in Turkmenistan and ends in the desert. ${ }^{21}$ Figure 1 schematically shows the geographical situation of the Harirud Basin, including the approximate location of the dams, main gauge stations and cities. Precipitation, which includes snow and rain, occurs mainly in the winter and spring. ${ }^{22}$ The mean annual precipitation is estimated at 236 millimetres $(\mathrm{mm})$ in the Afghan part with uneven spatial distribution. From March to June, high floods are observed in the Harirud River while from August to February there is a very low flow. ${ }^{23}$

The Harirud River is extremely important for Afghanistan, Iran and Turkmenistan from a socio-economic point of view. The economy of the basin and the income of a large portion of the population are highly dependent on the water resources of the river. About $50 \%$ of the gross domestic product (GDP) in the basin is linked directly to the agricultural sector (particularly in Afghanistan). The Harirud River contributes greatly to guaranteeing the security of food and drinking water, particularly in Herat

21 See, e.g., K. Frenken (ed.), 'Irrigation in Central Asia in Figures: AQUASTAT Survey-2012', Food and Agriculture Organization of the United Nations (FAO) Water Reports, No. 39, available at: http://www.fao.org/3/i3289e/i3289e.pdf.

K.J. Virgo, M.H. Aslami \& B. Ahmed, 'Participatory Watershed Management: Examples from Herat, Western Afghanistan', Proceedings of the World Association of Soil and Water Conservation, Paper No. P1, 30 Nov. 2006, pp. 65-81, at 67-8, available at: https://taa.org.uk/wp-content/uploads/2018/ 10/ Paper2\%20Virgo_Afghanistan_paper_11_24_06_final1.pdf.

23 S.K. Adhikary et al., 'Simulating Impacts of EFR Consideration on Reservoir Operation Policy and Irrigation Management in the Hari Rod River Basin, Afghanistan', 19th International Congress on Modelling and Simulation (MODSIM2011), Perth, WA (Australia), 12-16 Dec. 2011, available at: https://www.mssanz.org.au/modsim2011/I12/adhikary.pdf. 


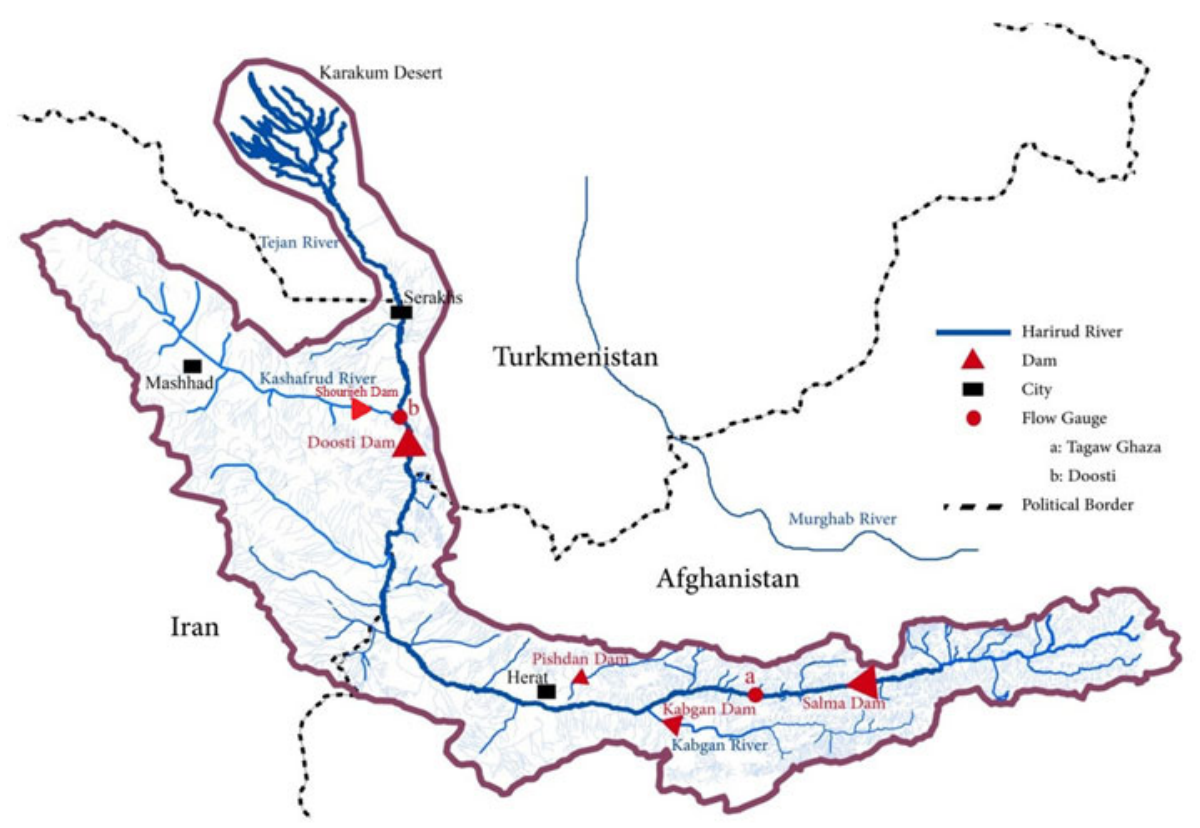

Figure 1 Geographical Map of the Harirud Basin (showing the dams with more than 50 million cubic metres (MCM) capacity)

and Mashhad. It contributes to supplying over $50 \%$ of the total domestic water demand of Mashhad, a large holy city in Iran which is visited by over 20 million pilgrims and tourists per year. ${ }^{24}$ The population of Afghanistan is also hugely dependent on this shared water resource. Herat, one of Afghanistan's major cities with an anticipated prosperous economic future, has great potential to develop rapidly, although it has seen insecurity caused by drought, war and internal conflicts. As a result of the long, devastating war in Afghanistan, the country has been labelled a least developed country, and the situation has forced many people to emigrate to other countries, mostly Iran. ${ }^{25}$ Therefore, water resources like the Harirud River play a strategic role in bringing security and income to the Afghan people. Table 1 shows the population of each riparian state living in the basin and the growth rate.

In the Harirud Basin, irrigation networks are currently distributed along the river, mostly in the lower basin from Herat in Afghanistan to Serakhs in Iran and Turkmenistan. Most of the irrigation systems in Herat which are still active today are traditional. The efficiency of the irrigation networks is about 25 to $30 \%$. Table 2 shows the irrigable land areas of the Harirud Basin in every riparian state. ${ }^{26}$

24 UNECE, n. 4 above, p. 129.

25 See, e.g., UN High Commissioner for Refugees (UNHCR), 'UNHCR Country Operations Profile: Islamic Republic of Iran' (2013) UNHCR Reports, available at: http://www.unhcr.org/539809fb0.pdf.

26 For more information about the geography and hydrology of the Harirud River Basin, see R. Favre \& G.M. Kamal, Watershed ATLAS of Afghanistan (Afghanistan Research and Evaluation Unit (AREU), 2004). 
Table 1 Population in the Harirud Basin

\begin{tabular}{lccccc}
\hline Country & $\begin{array}{c}\text { Area in } \\
\text { country }\left(\mathbf{k m}^{2}\right)\end{array}$ & $\begin{array}{c}\text { Country's } \\
\text { share }(\%)\end{array}$ & $\begin{array}{c}\text { Total } \\
\text { population }\end{array}$ & $\begin{array}{c}\text { Population density } \\
\left(\text { persons } / \mathbf{k m}^{2}\right)\end{array}$ & $\begin{array}{c}\text { Growth } \\
(\%)\end{array}$ \\
\hline Afghanistan & 39,300 & 39.5 & $1,290,000$ & 32 & 2.03 \\
Iran & 49,264 & 43.7 & $3,410,000$ & 69 & 1.25 \\
Turkmenistan & 23,640 & 20.9 & 168,000 & 7 & 1.14 \\
Total & 112,204 & 100 & $4,868,000$ & 43 & - \\
\hline
\end{tabular}

Source

M. King \& B. Sturtewagen, Making the Most of Afghanistan's River Basins: Opportunities for Regional Co-operation (EastWest Institute, 2010), p. 6.

Table 2 Irrigable Land Areas in the Harirud Basin

\begin{tabular}{lccc}
\hline Country & Area in the country (ha) & Irrigated land areas (ha) & Orchards and market garden (ha) \\
\hline Afghanistan & $3,930,000$ & 133,084 & 927 \\
Iran & $4,926,400$ & 292,920 & 14,113 \\
Turkmenistan & $2,364,000$ & N/A & N/A \\
\hline
\end{tabular}

Source

R. Favre \& G.M. Kamal, Watershed ATLAS of Afghanistan (Afghanistan Research and Evaluation Unit, 2004), pp. 125-9. See also Nagheeby, n. 20.

\subsection{Customary Distribution of the Harirud River Basin Flows}

Over $90 \%$ of the total flow in the Harirud River is supplied by annual snowfall and rain in the winter and spring in Afghanistan. ${ }^{27}$ This makes Afghanistan the main water contributor to the total water flows of the Harirud River, although there are some minor tributaries in Iranian territory.

According to the UN Food and Agriculture Organization (FAO), from 84,000 MCM of the volume of total annual surface waters in Afghanistan, the Harirud Basin has the potential for $1,600 \mathrm{MCM}^{28}$ The $\mathrm{FAO}$ points out that on average 1,070 MCM per year of surface waters in the Harirud River reach the Iranian border. This data is based on the situation as it was before the construction of the Salma Dam and thus does not take into account its impact. ${ }^{29}$

Generally, the groundwater is saline or brackish in the lower part of the Harirud Basin, such as in Herat and Serakhs. According to 1980s statistics, from total irrigated lands in Afghanistan, only $15.4 \%$ is supplied by aquifers through springs and deep/ shallow wells. The earlier data from the 1960 s illustrates that almost $98 \%$ of the

\footnotetext{
27 Favre \& Kamal, ibid., p. 82.

28 Frenken, n. 21 above.

29 Nagheeby, n. 20 above.
} 
irrigated area in Herat Province was irrigated by the surface water of rivers and not by groundwater. $^{30}$

\subsection{Control and Use of the Harirud River Flows}

Iran and Turkmenistan, without the involvement of Afghanistan, jointly funded the construction of the Doosti Dam, situated in the downstream zone. This work was based on an agreement between Iran and Turkmenistan signed in 1999. ${ }^{31}$ The Doosti Dam, with a reservoir volume of 1,250 MCM, was completed in 2004. According to the agreement, the water resources in the reservoir are shared equally between both countries. Iran uses the water of the Doosti Dam firstly for drinking purposes, secondly for agriculture, and then to meet industrial demand. In addition to the $182 \mathrm{~km}$-long pipeline to transfer water to the city of Mashhad in $2009,{ }^{32}$ Iran has also built several dams on the tributary river (Kashafrud River), which is located at the end of the basin.

In the upstream area of the Harirud River, with technical and financial support from the Indian government, Afghanistan has built the Salma Dam with a capacity of 633 MCM. This dam opened in 2016. ${ }^{33}$ Also financially and technically supported by the ADB, the Salma Dam will increase the irrigable lands from 35,000 to 80,000 hectares (ha) and produce 42 megawatts (MW) of electricity. ${ }^{34}$ In addition, Afghanistan has plans to build the Kabgan Dam with a reservoir capacity of almost $150 \mathrm{MCM}$ on the Kabgan tributary river, and the Pishdan Dam with 50 MCM reservoir capacity on the Karukh tributary river. ${ }^{35}$ Reportedly, waters behind these two latest dams will be transferred to the outside of the basin by Afghanistan for the exploitation of mines. ${ }^{36}$

\subsection{Ecological Importance}

The Harirud River ends in the desert of Karakum. According to Adhikary and co-authors, the Harirud Basin has an unstable ecological environment. ${ }^{37}$ The region located between the Tejan River and the Murghab River, which originates from the north of Afghanistan and flows to the south of Turkmenistan, is known as Badghyz. Located between the mountains and the sand desert of Karakum, the fauna and flora of Badghyz accordingly reflect the mixed bio-geographic connections. Covered by a

30 S. Chokkakula, Interrogating Irrigation Inequities, Canal Irrigation Systems in Injil District, Herat (AREU, 2009). See also Favre \& Kamal, n. 26 above.

31 Agreement on the Cooperation for the Construction and Operation of the Doosti Dam, Ashghabad (Turkmenistan), 20 Oct. 1999, between the government of the Islamic Republic of Iran and Turkmenistan, available at: http://rc.majlis.ir/fa/law/show/93319 (in Farsi).

32 See, e.g., S. Nairizi, 'Integrated Water Resources Management (IWRM) in the Critical Arid Basin of Iran (Mashhad Basin)', Power Point presentation (n.d.).

33 See n. 7 above.

34 Nathan Associates Inc. \& Louis Berger International Inc., 'Afghanistan Water Constraints Overview Analysis: Final Report', Report No. PB-93-180511/XAB, May 1992.

35 ADB, n. 17 above.

36 Nathan Associates Inc. \& Louis Berger International Inc., n. 34 above; see also Nagheeby, n. 20.

37 See Adhikary et al., n. 23 above. 
unique xeric savanna ecosystem, Badghyz is dominated by wild pistachio trees, which are recognized by many as similar to the African savanna. Many species in Badghyz are included in the International Union for the Conservation of Nature and Natural Resources (IUCN) or Turkmenistan Red Data Lists. Additionally, the Tejan valley, located near Serakhs in Iran and Turkmenistan, is recognized by BirdLife International as an Important Bird Area (IBA) as a result of the long-term viability of bird populations. ${ }^{38}$

\subsection{The Political Context and Existing Legal Institutions}

'Avoiding Water Wars: Water Scarcity and Central Asia's Growing Importance for Stability in Afghanistan and Pakistan', a 2011 report by the United States (US) Senate Foreign Relations Committee, warned of the growing disputes over transboundary waters between Afghanistan and its neighbouring countries. ${ }^{39}$ Similarly, acknowledging the importance of understanding the reasons behind these sentiments, ${ }^{40}$ the Norwegian Institute of International Affairs (NUPI) noted in 2008 that developing water infrastructure in Afghanistan over transboundary waters was an important driver of disputes and insecurity in the region. NUPI revealed that the geopolitical rivalries among China, India, Iran, Pakistan, Russia and the US, along with competition over water resources in Central Asia, are creating serious problems. Consequently, the political context of transboundary rivers is becoming more complex in the region. ${ }^{41}$

The first formal agreement regarding the allocation of water resources on the Harirud River is that between Iran and Russia, dating back to 26 February 1921, after Afghanistan had declared its independence in 1919. The third section of the agreement states that ' $[\mathrm{t}]$ he two states shall equally exploit the Atrak river and other border rivers and waters'. This was followed by the signing of an agreement on 20 February 1926 between Iran and Russia entitled 'Exploitation of Border Rivers and Waters along the Harirud River to the Caspian Sea'. ${ }^{42}$ Its first Article states that ' $[t]$ he entire water of the Harirud River (Tejan River) ... shall be divided between the two states in ten equal parts of which three parts shall belong to Iran and seven parts shall belong

38 V. Fet, 'Central Asia: Northern Afghanistan, Southern Turkmenistan, Southern Uzbekistan, Extending into Iran and Tajikistan', World Wide Fund for Nature (WWF), 2014, available at: http://worldwildlife. org/ecoregions/pa1306.

39 See, e.g., 'Avoiding Water Wars: Water Scarcity and Central Asia's Growing Importance for Stability in Afghanistan and Pakistan', Majority Staff Report, 22 Feb. 2011, available at: https:/www.foreign. senate.gov/imo/media/doc/Senate \%20Print \%20112-10\%20Avoiding\%20Water\%20Wars\%20Water \%20 Scarcity\%20and \%20Central\%20Asia\%20Afgahnistan\%20and\%20Pakistan.pdf. See also R.G. Palau, 'Afghanistan's Transboundary Water Resources: Regional Dimensions', Civil-Military Fusion Centre, July 2011.

40 A.E. Cascão et al., 'Why Are Water Wars Back on the Agenda? And Why We Think It's a Bad Idea!', FLOWs, 22 Mar. 2018, available at: https://flows.hypotheses.org/1126.

41 See, e.g., Heidi Kjærnet \& Stina Torjesen, Afghanistan and Regional Instability: A Risk Assessment (Norwegian Institute of International Affairs, 2011). For an extensive discussion, see Nagheeby $\&$ Warner, n. 11 above.

42 See Agreement on the Regimes of Border Rivers, 26 Feb. 1921, between the Imperial Government of Iran and the Union of Soviet Socialist Republics, and Agreement on the Regimes of Border Rivers, 20 Feb. 1926, between the Imperial Government of Iran and the Union of Soviet Socialist Republics. 
to the Soviet Union'. In addition to the water allocation provisions, both states agreed on the construction of a dam on the Harirud River with equal water allocation. In March 1958, the construction of a common dam was the subject of negotiations between Iran and Russia, which resulted in a number of pilot studies of the dam being undertaken.

Eventually, in 1974 Iran and Russia began specific negotiations, subject to the 1926 and 1958 agreements, to construct a common dam downstream. However, in 1976 it was revealed that Afghanistan had been trying to build the Salma Dam on the upstream river. $^{43}$ This Afghan project involved Indian and British experts, as well as the World Bank. Cognizant of Afghanistan's decision to build a dam in the upper reaches of the river, Iran and the Soviet Union, in 1975, emphasized the necessity for trilateral cooperation among the three riparian states. However, Afghanistan did not respond to this political signal. The unilateral efforts to construct a dam by the riparian states of the Harirud River were stopped by the Soviet Union's invasion of Afghanistan in 1979 and Iraq's invasion of Iran in $1980 .^{44}$

Negotiations between Iran and the Soviet Union on the construction of a common dam on the downstream Harirud River, based on the 1926 agreement, resumed in 1992 between Iran and the newly formed republic of Turkmenistan, established after the collapse of the Soviet Union. Iran and Turkmenistan agreed in 1999 to share the water resources of the Doosti Dam reservoir equally. ${ }^{45}$ Further to the 1999 agreement, the two countries started the construction of the Doosti Dam in 2000, and officially opened the dam in 2004. Consequently, according to the EastWest Institute - an international think tank - Afghanistan complained to Iran and Turkmenistan that it had not been consulted over the construction of the dam. ${ }^{46}$ Afghanistan's concern about the Doosti Dam, as we argue, might be justified under the concept of 'historical water rights' or 'existing water rights', which are likely to be claimed by Iran and Turkmenistan in the future - perhaps giving them the upper hand in negotiations in the context of international water law. ${ }^{47}$ Furthermore, according to Salman, the building of such a dam by the downstream states may adversely affect future uses of the waters of the shared watercourse by the upstream state. ${ }^{48}$ On the other hand, although the construction of the Salma Dam had been planned since 1976 by Afghanistan with Indian and British support, the country could not make physical progress on its construction because of the conflict and civil wars in the country. After

43 See Nagheeby \& Warner, n. 11.

44 For more detailed analysis, see Nagheeby \& Warner, n. 11 above.

45 See Agreement on the Construction and Operation of the Doosti Dam, 20 Oct. 1999, between the Government of the Islamic Republic of Iran and the Government of Turkmenistan Republics, Art. 9, available at: http://rc.majlis.ir/fa/law/show/93319.

46 See EastWest Institute, n. 6 above.

47 Certain legal doctrines in the context of water law, and particularly under the law of prior appropriation, posit that the first person to obtain the water for his own beneficial use has priority over water allocation: see, e.g., A.D. Tarlock, 'Prior Appropriation: Rule, Principle, or Rhetoric' (2000) 76(4) North Dakota Law Review, pp. 881-910, at 881.

48 M.A. Salman, 'Downstream Riparians Can Also Harm Upstream Riparians: The Concept of Foreclosure of Future Uses' (2010) 35(4) Water International, pp. 350-64. 
11 September 2001 and the start of President Karzai's time in office, the USD 200 million Salma Dam project, a budget which ultimately rose to USD 300 million, was initiated by the Indian government. ${ }^{49}$

In addition to the Salma Dam, Afghanistan is developing several new irrigation schemes along the Harirud River with the support from the ADB under the Western Basins Water Resource Management and Irrigated Agriculture Development Project. ${ }^{50}$ It is argued that Afghanistan sought to complete hydraulic projects such as the Salma Dam on the Harirud Basin in the face of previously constructed infrastructure by downstream countries to improve its bargaining position in likely future negotiations. ${ }^{51}$

Meanwhile, recalling the overtures of Iran and Russia towards negotiations in 197576, which had been rebuffed by Afghanistan, in 2006 and again in 2010 Iran and Turkmenistan jointly sent an official letter to President Karzai with an invitation for trilateral cooperation on the Harirud River. These invitations also went unanswered. ${ }^{52}$ As Mahmoud Saikal, a former Afghan diplomat, mentioned on Afghan television: 'We [Afghans] received a letter from Iran and Turkmenistan in 2006, asking for cooperation on the Harirud River, but we [Afghans] responded to them that we do not want to talk about our waters'. ${ }^{53}$ More recently, Fazl Ahmad Zakeri, the Ministry of Energy and Water's Former Acting Director for the Harirud and Murghab River Basin in Heart, answered 'Yes, the Iranians are asking for negotiations. They are always asking for negotiations [because they will get] much less water'. ${ }^{54}$ Afghanistan's unwillingness to cooperate on transboundary waters in the region is also clearly documented in the words of Afghan official Shujaudin Ziaye: ${ }^{55}$ 'Maybe they [Iran and Turkmenistan] need to talk with us, but we don't see any need to talk with them, to negotiate about water. Right now, no'. 56

This message that there is 'no need for negotiation concerning the Harirud River' from the Afghan side continued until recently and created concerns for downstream users. As a result, Iranian President Rohani raised the concern that 'Iran could not be silent about the environment of the region and negative impacts arising from dam development in Afghanistan'. 57

A round of negotiations took place in June and October 2017 between Iran and Afghanistan (but not Turkmenistan) in Tehran (Iran) and Kabul (Afghanistan)

49 See Pant, n. 12 above.

50 See ADB, n. 17 above.

51 See V. Thomas \& J. Warner, 'Hydro-politics in the Harirud/Tejen River Basin: Afghanistan as Hydrohegemon?' (2015) 40(4) Water International, pp. 593-613. See also Nagheeby \& Warner, n. 11 above.

52 See, e.g., 'BA REWAYATE DIGAR: Water Resources of Afghanistan', Tolo News, 26 Aug. 2013, available at: http:/www.tolonews.com/en/ba-rewayate-digar/11685-ba-rewayate-digar-water-resources-ofafghanistan.

53 Ibid.

54 Peterson, n. 8 above.

55 The former deputy Minister of Energy and Water in Kabul.

56 Peterson, n. 8 above.

57 'Rohani's Criticism of Irregular Dam Building by Neighbouring Countries', Hamshahri Online News, 4 July 2017, available at: http://www.hamshahrionline.ir/details/375052 (in Farsi). 
respectively regarding a 'Comprehensive Strategic Partnership' on various issues, mostly related to security and water. ${ }^{58}$ Simultaneously, local media revealed related negotiations between Afghanistan and Turkmenistan. ${ }^{59}$ However, the media has not yet reported any meaningful progress to indicate Afghanistan's genuine interest in negotiating matters regarding the Harirud waters with Iranian and Turkmen officials. Thus, a question mark remains over the legal regime concerning the utilization/allocation of the Harirud waters and the legitimacy of dam buildings therein.

\section{THE LEGITIMACY OF DAM BUILDING UNDER INTERNATIONAL LAW}

\subsection{Assessing Legitimacy}

In this section we assess not just the legality but the legitimacy of the construction of the dam in the international watercourse. Perhaps it is necessary first to describe what is legal and what is legitimate. Generally, legality requires compliance with the applicable law and rules. Legitimacy, however, involves the implication of correct, fair and justified actions. Legitimacy is characterized by what is achieved with justice and what is deserved. Therefore, in this section, we first elaborate on the international rules applicable to the construction of a dam on a transboundary river. Further, in a broader analysis, we will address other issues involved which could be used to justify unilateral dam development. International water law as treaty law is limited to the 1997 UNWC and the 1992 UNECEWC, ${ }^{60}$ but these conventions fail to provide more than a framework for further cooperation. In this article, international water law is considered as customary rules and principles to guide water conflict resolution. Thus, here, the 1997 UNWC, considered to be customary law, is used as the basis for the legal framework, and we examine the transboundary water interaction in the light of legitimacy as an analytical lens grounded on the legal framework. Furthermore, not all watercourse states are party to these conventions. The landscape of international water law is broader than the UNWC and UNECEWC. International environmental law regimes, such as those under the 1971 Convention on Wetlands of International Importance especially as Waterfowl Habitat (Ramsar Convention) ${ }^{61}$ and the 1992 Convention on Biological Diversity (CBD), ${ }^{62}$ are undoubtedly of importance as well for new

58 'Iran, Afghanistan Open Talks on Comprehensive Strategic Partnership', Tasnim News Agency, 19 June 2017, available at: https:/www.tasnimnews.com/en/news/2017/06/19/1440459/iran-afghanistan-opentalks-on-comprehensive-strategic-partnership.

59 'Afghanistan, Turkmenistan Sign Bilateral Agreements', Tolo News, 4 July 2017, available at: https://www.tolonews.com/business/afghanistan-turkmenistan-sign-bilateral-agreements.

60 N. 19 above.

61 Ramsar (Iran), 2 Feb. 1971, in force 21 Dec. 1975, available at: https://www.ramsar.org; as amended by the Paris Protocol, Paris (France), 3 Dec 1982, in force 1 Oct. 1986, available at: https://www.ramsar. org/document/the-paris-protocol-to-the-ramsar-convention-on-wetlands; and the Regina Amendments, Regina, SK (Canada), 28 May 1987, in force 1 May 1994, available at: https://www.ramsar.org/document/the-regina-amendments-to-the-convention-on-wetlands.

62 Rio de Janeiro (Brazil), 5 June 1992, in force 29 Dec. 1993, available at: https://www.cbd.int. 
infrastructure projects on international watercourses. Moreover, the concept of legitimacy unavoidably requires broader scrutiny than merely analyzing sources of international water or environmental law and human rights law, since concepts of distributive justice and equity also play a role in assessing legitimacy.

The literature on the management of international watercourses has addressed the relationship between legitimacy and distributive justice. Yihdego and Rieu-Clarke describe legitimacy as 'procedural fairness' and associate distributive justice with substantive principles of international water law. ${ }^{63}$ The authors argue that 'procedural fairness [legitimacy] and distributive justice [substantive rules], as normative standards, constitute two sides of the same coin, which, in turn, demands that both are considered together when analysing the merits of transboundary treaty frameworks'.64 International water law, and particularly the UNWC, demonstrate a significant correlation between these functions. For instance, Articles 6 and 11-19 UNWC show a clear linkage between the substantive principles of equitable utilization and the procedural obligations within the duty to cooperate, notify and consult. We will now analyze the various sources that can inform an assessment of legitimacy.

\subsection{Sovereignty}

The starting point for assessing the legitimacy of dam development on a shared watercourse is still the concept of sovereignty. Sovereignty is a key reference point for international water utilization doctrines. ${ }^{65}$ On the one hand, a state has sovereignty over its natural resources as well as the right of development. The sovereign right to exploit natural resources should indeed not impose harmful effects on other states. As an accepted principle of international law, which is recognized by the International Court of Justice (ICJ) and tribunals in several cases such as the Lake Lanoux Arbitration, ${ }^{66}$ states have the sovereign right to utilize their natural resources. ${ }^{67}$ Therefore, unilaterally damming a shared watercourse could be justified by the sovereign right of that particular state with absolute territorial sovereignty. However, the sovereignty of states is not absolute. The scope of its application is limited to specific circumstances. ${ }^{68}$ The ICJ in the Gabčikovo-Nagymaros case held that the right of a sovereign state unilaterally to build a dam on a shared watercourse completely within its territory is still subject to particular limitations. There is, firstly, the duty not to cause significant transboundary damage and, secondly, the duty to respect the equitable and reasonable utilization of a

63 For a detailed discussion, see Yihdego \& Rieu-Clarke, n. 3 above.

64 Ibid., p. 545 (added text inside square brackets).

65 R.L. Farnum, S. Hawkins \& M. Tamarin, 'Hydro-Hegemons and International Water Law', in A. Rieu-Clarke, A. Allan \& S. Hendry (eds), Routledge Handbook of Water Law and Policy (Taylor \& Francis, 2017), pp. 297-310.

66 Lake Lanoux Arbitration (France v. Spain), Arbitral Tribunal, 16 Nov. 1957, (1957) 12 Reports of International Arbitral Awards, p. 281.

67 See R. Pereira \& O. Gough, 'Permanent Sovereignty over Natural Resources in the $21^{\text {st }}$ Century: Natural Resource Governance and the Right to Self-determination of Indigenous Peoples under International Law' (2013) 14(2) Melbourne Journal of International Law, pp. 451-95.

68 Y. Tyagi, 'Permanent Sovereignty over Natural Resources' (2015) 4(3) Cambridge Journal of International \& Comparative Law, pp. 588-615, at 588. 
shared watercourse. ${ }^{69}$ As a result, a riparian state will have the right to build a dam on a shared watercourse but such a right is limited and the state must comply with other international obligations. This reasoning signifies that limited territorial sovereignty is now the accepted theory for the utilization of shared watercourses in international law. $^{70}$

Moreover, water has always been considered separately from other natural resources because of the unique dependence of humans on water. The literature therefore refers to an at-best limited but not absolute sovereignty over a shared watercourse. ${ }^{71}$ In sum, the state of origin will have the basic right to utilize the shared watercourse, but this utilization must comply with the international obligations of the state of origin. ${ }^{72}$ This balanced approach is reflected precisely in the concept of equitable and reasonable utilization of the watercourse. ${ }^{73}$

\subsection{The 1997 UN Watercourses Convention}

Article 38 of the Statute of the International Court of Justice ${ }^{74}$ outlines international conventions, international customary law and the general principles of law recognized by civilized nations as the main sources of international law. Keeping these sources in mind, the question of which formal obligations under international law govern the construction of a dam is particularly complex in this particular case, as there is no formal treaty between Turkmenistan, Iran and Afghanistan that covers the issue. As a result, two treaties could potentially play a role: the UNECEWC, ${ }^{75}$ and the UNWC. ${ }^{76}$ Since riparian states in the case of the Harirud River dam have not acceded to either Convention, with the exception of Turkmenistan's membership of the

69 See S. McCaffrey, 'The Contribution of the UN Convention on the Law of the Non-Navigational Uses of International Watercourses' (2001) 1(3-4) International Journal of Global Environmental Issues, pp. 250-63.

70 Farnum, Hawkins \& Tamarin, n. 65 above, p. 301.

71 J.W. Dellapenna, 'Treaties as Instruments for Managing Internationally Shared Water Resources: Restricted Sovereignty vs. Community of Property' (1994) 26(1) Case Western Reserve Journal of International Law, pp. 27-56, at 27; see also C. Mendis, 'Sovereignty vs. Transboundary Environmental Harm: The Evolving International Law Obligations and the Sethusamuduram Ship Channel Project', UN Division for Ocean Affairs and the Law of the Sea, Office of Legal Affairs, 2006.

72 See further N. Schrijver, Sovereignty over Natural Resources: Balancing Rights and Duties (Cambridge University Press, 1997), pp. 231-52.

73 See also L. Chiussi, 'United Nations Convention on the Law of the Non-Navigational Uses of International Watercourses', in M. Fitzmaurice, A. Tanzi \& A. Papantoniou (eds), Multilateral Environmental Treaties (Edward Elgar, 2017), pp. 247-56, at 251 (arguing that the roots of the norm of equitable and reasonable use are to be found in the necessity to elaborate a mediating paradigm of redistributive justice between the absolute territorial sovereignty of the upstream state to use and consume the waters of the international watercourse and the absolute territorial integrity of the downstream state). See also McCaffrey, n. 69 above, and see S. Pahuja, Decolonising International Law: Development, Economic Growth and the Politics of Universality (Cambridge University Press, 2013).

74 San Francisco, CA (US), 26 June 1945, in force 24 Oct. 1945, available at: https:/www.icj-cij.org/en/ statute.

75 C. Contartese, 'Convention on the Protection and Use of Transboundary Watercourses and International Lakes 1992 (The UNECE Helsinki Convention)', in Fitzmaurice, Tanzi \& Papantoniou, n. 73 above, pp. 257-68.

76 Chiussi, n. 73 above, pp. 247-56; P. Sands \& J. Peel, Principles of International Environmental Law, $3^{\text {rd }}$ edn (Cambridge University Press, 2012), pp. 310-12. 
UNECEWC, ${ }^{77}$ neither the UNWC nor the UNECEWC is formally binding in this case. While each Convention could make a positive contribution to strengthening transboundary water cooperation, ${ }^{78}$ the emphasis of this article is placed on the UNWC.

Far more than the UNECEWC, the UNWC reflects the substantive and procedural norms of customary international law, in particular under the principle of equitable and reasonable utilization. ${ }^{79}$ For the formation of customary international law two elements are required: opinio juris and state practice. In this connection, the UNWC was adopted by the UN General Assembly after preparatory work by the International Law Commission (ILC). The ILC plays an important role in the identification of customary law.

Furthermore, the UNWC consists of substantive and procedural norms that are completely interrelated. Substantive norms can be listed briefly as equitable and reasonable utilization, the no-harm principle, and a general obligation to cooperate. Procedural norms provide guidelines to states on how to implement their substantive obligations and include the obligation to exchange data and information regularly, to provide information concerning planned measures, and further consultation on the potential effects of such planned measures. All these principles form part of the corpus of international law and reflect customary international law, ${ }^{80}$ which means that they are binding upon all states. ${ }^{81}$ This argument is supported by decisions of the ICJ in the Gabčíkovo-Nagymaros (Hungary/Slovakia) case $^{82}$ as well as in Pulp Mills on the River Uruguay (Argentina v. Uruguay). ${ }^{83}$ Furthermore, the global influence of the UNWC is demonstrated in state practice - namely, the development of water treaty arrangements such as the Southern African Development Community Revised Protocol

77 Turkmenistan officially joined the 1992 UNECEWC on 29 Aug. 2012.

78 Considering the similarities and differences between the Conventions and the fact that they are currently in operation at the global level, promoting and implementing both Conventions as a 'package' creates more synergistic benefits beyond that of either Convention standing alone. Rieu-Clarke and Kinna suggest a 'package approach' to the implementation of both Conventions in order to strengthen the law of international watercourses: A. Rieu-Clarke \& R. Kinna, 'Can Two Global UN Water Conventions Effectively Co-exist? Making the Case for a "Package Approach" to Support Institutional Coordination' (2014) 23(1) Review of European, Comparative \& International Environmental Law, pp. 15-31.

79 F.R. Loures, A. Rieu-Clarke \& W. Joseph, 'The Authority and Function of the UN Watercourses Convention', in F.R. Loures \& A. Rieu-Clarke (eds), The UN Watercourses Convention in Force: Strengthening International Law for Transboundary Water Management (Routledge, 2013), pp. 4966, at 52; see also A.S. Rieu-Clarke, 'The UN Watercourse Convention', in A. Rieu-Clarke, A. Allan \& S. Hendry (eds), Routledge Handbook of Water Law and Policy (Taylor \& Francis, 2017), pp. 193-204, at 194.

These core principles have formed the bedrock of bi- and multilateral agreements: see L. Boisson de Chazournes, Fresh Water in International Law (Oxford University Press, 2013). The principles are also centred on the 2008 ILC Draft Articles on the Law of Transboundary Aquifers, 2008(II) Yearbook of the International Law Commission, Part 2 (Draft Aquifer Articles), available at: http://legal.un.org/ilc/texts/instruments/english/commentaries/8_5_2008.pdf, and the 1992 UNECEWC.

81 McCaffrey, n. 69 above.

82 Gabčikovo-Nagymaros Project (Hungary v. Slovakia), Judgment (Merits), 25 Sept. 1977, ICJ Reports (1997), p. 7.

83 Pulp Mills on the River Uruguay (Argentina v. Uruguay), Judgment, 20 Apr. 2010, ICJ Reports (2010), p. 14. 
on Shared Watercourses, ${ }^{84}$ and the Nile Basin Cooperative Framework Agreement. ${ }^{85}$ The UNWC, therefore, partly codifies customary international law in this field.

In addition, considering that the contemporary international order is grounded on consent and self-interest, states have a conservative approach towards entering into farreaching, binding detailed commitments and prefer 'looser and more flexible "framework" agreements' ${ }^{86}$ In this regard, by exploring similarities and differences, Tanzi concludes that, in general, the UNECEWC provides more detail with regard to practical matters and institutional arrangements compared with the UNWC. ${ }^{87}$ Hence, the UNWC represents perhaps a more acceptable legal framework for states by requiring general duties and rights. It is therefore instructive to look at the UNWC as a global instrument adopted by the ILC in order to address the principles of international customary law. We discuss each principle in more detail in the following sections.

\subsection{The Equitable and Reasonable Utilization Principle}

To resolve the challenges of states in utilizing shared water resources, several doctrines have been adopted by states and by international instruments. ${ }^{88}$ Four theoretical principles - including territorial sovereignty, territorial integrity, equitable utilization, and common management - have been used in allocating the resources of watercourses. ${ }^{89}$ Among these principles, equitable utilization represents customary international law. ${ }^{90}$ This principle states simply that the substantial interests of all riparian states should be reconciled in the most effective way.

The equitable and reasonable utilization of shared watercourses is one of the fundamental principles of international water law. According to McIntyre, it implies that the utilization of a shared watercourse should be conducted by taking into account a list of factors which allow the assessment of, and respect for, the interests of all the watercourse states involved. ${ }^{91}$ Therefore, the equitable and reasonable utilization principle requires the implementation of a decision-making strategy in which various aspects of the utilization of a shared watercourse must be examined. In addition, the principle

84 Revised Protocol on Shared Watercourses in the Southern African Development Community, Windhoek, Namibia (South Africa), 7 Aug. 2000, in force 22 Sept. 2003, available at: https://www.sadc.int/documents-publications/show/1975.

85 Agreement on the Nile River Basin Cooperative Framework, 1 Aug. 2009, available at: http://www.inter nationalwaterlaw.org/documents/regionaldocs/Nile_River_Basin_Cooperative_Framework_2010.pdf.

86 D. Armstrong, T. Farrell \& H. Lambert, International Law and International Relations (Cambridge University Press, 2012), p. 288.

87 See further A. Tanzi, The Consolidation of International Water Law: A Comparative Analysis of the UN and UNECE Water Conventions (Editoriale Scientifica Napoli, 2017). See further also Contartese, n. 75 above, pp. 265-6.

88 See S. Dinar, International Water Treaties: Negotiation and Cooperation along Transboundary Rivers (Routledge, 2007), pp. 39-41.

89 N. Islam, The Law of Non-Navigational Uses of International Watercourses: Options for Regional Regime-Building in Asia, Vol. 8 (Kluwer Law International, 2010), pp. 102-11.

90 It is reflected in the UNWC and Draft Articles on Transboundary Aquifers, n. 80 above. See further Dellapenna, n. 71 above.

91 O. McIntyre, Environmental Protection of International Watercourses under International Law (Routledge, 2016). 
of equitable and reasonable utilization of a shared watercourse was expressly considered as part of customary international law in the ICJ decision concerning the Gabčikovo-Nagymaros project, a conflict between Hungary and Slovakia which also involved the construction of a dam. ${ }^{92}$ The principle is also articulated in Article 5 UNWC and in Article 12 of the Berlin Rules 2004. ${ }^{93}$ Hence, there is no doubt that unless otherwise agreed by riparian states, such states are obliged to use shared watercourses in an equitable and reasonable manner. ${ }^{94}$ The question which may arise is how such equitable and reasonable utilization should be defined and agreed by the riparian states.

Several concerns arise regarding the evaluation of equitable and reasonable utilization. As McCaffrey correctly asks, 'how can an upstream state know if it is using an international watercourse in an equitable manner?" 95 In the absence of joint management of a shared watercourse, it may be difficult to determine whether a shared watercourse is used equitably and reasonably. Article 6 UNWC lists, in a non-exhaustive manner, a number of factors that should be considered in evaluating equitable and reasonable utilization, such as population dependence, the availability of alternatives, and the effects of the shared water utilization. Riparian states, therefore, must utilize the shared water by considering these factors and by taking into account the interests of other riparian states as well as the ecosystem of the shared watercourse. There could still be a challenge for an equitable balancing of the diversity of state interests, as implementing these factors without reference to political intent would be onerous. Therefore, some authors express concern about the practical application of these factors. ${ }^{96}$ Moreover, each riparian state may have a different evaluation of these factors and give different weight to them, which may also lead to disagreement among riparian states. Other authors suggest that equitable utilization should be determined with reference to fairness and norms of distributive justice. ${ }^{97}$ Therefore, the interests of riparian states should be taken into consideration in the evaluation of these factors. This implies that such evaluations of fairness and distributive justice in the context of water allocation should not be rendered without particular attention being paid to the special needs of the least developed states. In this connection, one may argue that distributional

92 Gabčikovo-Nagymaros (Hungary v. Slovakia), n. 82 above.

93 The Berlin Rules on Water Resources were approved by the Water Resources Law Committee of the International Law Association (ILA) in 2004. These Rules set out customary international law relating to freshwater resources: ILA, Report of the $71^{\text {st }}$ Conference 3, (2004) 71 ILA 337, 385.

94 See further McCaffrey, n. 69 above; and J.W. Dellapenna, 'The Customary International Law of Transboundary Fresh Waters' (2001) 1(3-4) International Journal of Global Environmental Issues, pp. 264-305. See also F. Daibes-Murad, A New Legal Framework for Managing the World's Shared Groundwaters (IWA Publishing, 2005), p. 97; and Islam, n. 89 above, p. 161.

95 McCaffrey, n. 69 above.

96 Dellapenna, n. 71 above. For a discussion of different perspectives on defining 'justice' and 'equity', see also M. Zeitoun et al., 'Transboundary Water Justice: A Combined Reading of Literature on Critical Transboundary Water Interaction and "Justice", for Analysis and Diplomacy' (2014) 16(S2) Water Policy, pp. 174-93.

97 O. McIntyre, 'Utilization of Shared International Freshwater Resources: The Meaning and Role of "Equity" in International Water Law' (2013) 38(2) Water International, pp. 112-29; see also U. Trilochan, International Watercourses Law and Its Application in South Asia (Pairavi Prakashan, 2006), pp. 108-9. 
equity requires richer states to provide assistance to poorer states in order to enable them to utilize shared watercourses in a more efficient manner. ${ }^{98}$

These concerns regarding the evaluation of equitable and reasonable utilization serve as an important rationale for the implementation of procedural obligations. As a result, only through an effective implementation of procedural obligations could substantive obligations be fully evaluated and complied with by the riparian states.

\subsection{The No-Harm Principle}

The no-harm principle is widely expressed in the case law of the ICJ and is articulated in several international and regional legal instruments. ${ }^{99}$ It is cited in the Trail Smelter Arbitration, ${ }^{100}$ the Corfu Channel, ${ }^{101}$ the Nuclear Tests, ${ }^{102}$ and the Pulp Mills ${ }^{103}$ cases. It is also reflected in Principle 21 of the Stockholm Declaration ${ }^{104}$ and Principle 2 of the Rio Declaration, ${ }^{105}$ the ILC Draft Articles on Prevention of Transboundary Harm from Hazardous Activities 2001, ${ }^{106}$ Article 7 UNWC, and many other international instruments.

For example, in the Lake Lanoux Arbitration (France v. Spain) ${ }^{107}$ Spain argued that a French plan to divert water from Lake Lanoux to generate hydro-electric energy would violate its water rights under a series of treaties and brought the case before an arbitration tribunal. The tribunal rejected Spain's arguments because the French plan would not alter the volume of water entering Spain. Here, the tribunal relied on

98 McIntyre, ibid., pp. 126-8: see also M. Zeitoun, 'The Relevance of International Water Law to Later-Developing Upstream States’ (2015) 40(7) Water International, pp. 949-68.

99 See, e.g., J. Albers, Responsibility and Liability in the Context of Transboundary Movements of Hazardous Wastes by Sea: Existing Rules and the 1999 Liability Protocol to the Basel Convention, Vol. 29 (Springer, 2014), p. 152.

100 Trail Smelter Arbitration (United States v. Canada), Trail Smelter Arbitral Tribunal, 16 Apr. 1938 , 3 Reports of International Arbitral Awards, p. 1905, at 1911-37.

101 Corfu Channel Case (United Kingdom v. Albania), Judgment (Merits), 9 Apr. 1949, ICJ Reports (1949), p. 4 , at 43 .

102 Nuclear Tests Case (Australia v. France), Judgment, 20 Dec. 1974, ICJ Reports (1974), p. 253; Nuclear Tests Case (New Zealand v. France), Judgment, 20 Dec. 1974 ICJ Reports (1974), p. 457.

103 N. 83 above.

104 Declaration of the UN Conference on the Human Environment, adopted by the UN Conference on Environment and Development, Stockholm (Sweden), 5-16 June 1972, UN Doc. A/Conf.48/14/Rev. 1, available at: http://www.un-documents.net/aconf48-14r1.pdf.

105 Declaration on Environment and Development, adopted by the UN Conference on Environment and Development (UNCED), Rio de Janeiro (Brazil), 3-14 June 1992, UN Doc. A/CONF.151/26/Rev.1 (Vol. I), Annex I, available at: http://www.un.org/documents/ga/conf151/aconf15126-1annex1.htm; Agenda 21: A Programme for Action for Sustainable Development, Rio de Janeiro (Brazil), 3-14 June 1992, in Report of the UNCED, Annex II, UN Doc. A/CONF.151/26 (Vol. II) (1992); Non-Legally Binding Authoritative Statement of Principles for a Global Consensus on the Management, Conservation and Sustainable Development of all Types of Forests, Rio de Janeiro (Brazil), 13 Jun. 1992, in Report of the UNCED, UN Doc. A/CONF.151/26 (Vol. III), available at: https://www.un.org/documents/ga/conf151/aconf15126-3.htm.

106 Adopted by the ILC at its $53^{\text {rd }}$ session in 2001, and submitted to the UN General Assembly as a part of the Commission's report covering the work of that session (UN Doc. A/56/10). The report, which also contains commentaries on the draft articles, appears in 2001(II) Yearbook of the International Law Commission, Part Two.

107 N. 66 above. 
the French promise to return water to Spain. If the volume of water entering Spain had reduced significantly, perhaps the award of the tribunal would have been different. ${ }^{108}$

Therefore, the no-harm principle as a customary rule is undoubtedly applicable and binding upon states. Article 3 of the ILC Draft Articles of 2001 expresses that 'the [s]tate of origin shall take all appropriate measures to prevent significant transboundary harm or at any event to minimize the risk thereof'. Similarly, but more limited in coverage, Article 7 UNWC requires watercourse states to take all appropriate measures to prevent causing significant harm to other watercourse states in utilizing an international watercourse in their territories.

In general, this principle limits the scope of the sovereign rights of states. ${ }^{109}$ The sovereign right of a state to exploit its own resources is limited by the responsibility to ensure that activities within its jurisdiction or control do not cause damage to the environment of other states or of areas beyond the limits of national jurisdiction. This principle also implies that the state in which any activity is planned (the state of origin) should take all appropriate measures to prevent causing significant transboundary damage beyond its territory or control.

Transboundary damage refers to any adverse impact that results from activities carried out in one country which cause significant damage in the territory of another country. Hence, four elements need to be present for transboundary damage to occur: (i) a human cause of transboundary damage; (ii) significant adverse impacts; (iii) a causal link between activities carried out in the territory of, or under the control of, one country and harm incurred in the territory of another state; and (iv) the transboundary movement of such harmful impact. ${ }^{110}$ If transboundary damage is established, the principle places a due diligence obligation upon the state of origin to take all appropriate measures. This raises the question of which measures are considered appropriate? Unsurprisingly, states have a great deal of discretion in choosing appropriate measures. Generally, states have the authority to decide which measures should be taken and which activities should be governed by preventive measures. ${ }^{111}$ Furthermore, if a development over a river basin reflects the criteria of the equitable and reasonable utilization principle, it arguably meets the no-harm principle. Similar to the principle of equitable and reasonable utilization, the no-harm principle can be perceived through a substantive and a procedural lens. The substantive aspects of the principle deal with the threshold of transboundary damage. The procedural dimension of no harm clarifies the specific obligations with which states should comply to prevent transboundary damage. The substantive and procedural implications of the no-harm principle, however, have been developed in different instruments.

According to Article 7 UNWC, watercourse states should prevent the causing of significant harm to other watercourse states. Therefore, the threshold that is used for

108 See also the Indus Waters Kishenganga Arbitration (Pakistan v. India), Permanent Court of Arbitration (PCA), Final Award, 20 Dec. 2013, ICGJ 478 (PCA 2013).

109 Cf. Section 3.2.

110 H. Xue, Transboundary Damage in International Law, Vol. 27 (Cambridge University Press, 2003), pp. 4-10.

111 Zeitoun, n. 98 above. 
qualifying transboundary damage is 'significance': the obligation of watercourse states is limited to the duty not to cause significant transboundary harm. ${ }^{112}$ The same threshold is used in the ILC Draft Articles of 2001. Meanwhile, neither instrument gives any further indication of the activities coming within the scope of the defined threshold. Only the ILC indicates that it includes activities which are not prohibited under international law. Hence, the utilization of a shared watercourse, which as Article 7 confirms is not prohibited under international law, could still be considered unlawful and beyond the legitimate rights of each of the riparian states. If it leads to constant transboundary damage to other riparian states, this use could be considered unlawful utilization unless due diligence has been exercised.

However, there remains a question of the circumstances in which the utilization of shared watercourses could be considered lawful but leads to transboundary damage. In dealing with this question, McIntyre links the no-harm principle with the principle of equitable utilization. He further argues that the prohibition on causing significant harm could be reached only by taking into account factors that are relevant to the application of the principle of equitable utilization, and many of these factors are environmental in nature. Hence, in evaluating these factors, as a substantive implication of the no-harm principle in the shared watercourse, one should consider the environmental impacts of utilizing such a shared watercourse. Furthermore, the notion of sustainability implies that the interests of all communities related to the shared watercourse, as well as environmental factors, should be given priority in using that watercourse. Hence, McIntyre concludes that preventing transboundary damage to a large extent is included within the determination of a reasonable and equitable regime. ${ }^{113}$

Some commentators claim that, taking into account the position of the no-harm principle in customary international law, it should be given primacy over the equitable and reasonable utilization principle. ${ }^{114}$ Others maintain that the equitable and reasonable utilization principle should be given priority over the no-harm principle. ${ }^{115}$ Indeed, the obligation of watercourse states to prevent transboundary damage should not be considered without taking into account other provisions set out in the UNWC. Any development of a shared watercourse may cause harm to other riparian states, however slight. ${ }^{116}$ Therefore, inevitably an upstream state will cause some degree of harm to a downstream state through its use of a shared watercourse. In the light of recent developments in international law, arguably the no-harm and equitable and reasonable utilization principles should be interpreted in combination with other international norms such as sustainable development. One may argue, therefore, that the equitable and reasonable utilization principle is flexible enough to imply an additional obligation not to cause significant harm. As a result, it is possible to interpret the

112 See further Chiussi, n. 73 above, p. 252.

113 McIntyre, n. 91 above, p. 105.

114 See Daibes-Murad, n. 94 above, p. 92.

115 See S.M.A. Salman, The World Bank Policy for Projects on International Waterways: An Historical and Legal Analysis (World Bank, 2009), p. 96.

116 S. McCaffrey, The Law of International Watercourses (Oxford University Press, 2007), Ch. 10-11. 
UNWC in a manner that avoids difficulties and disputes over the interpretation of the principle of equitable and reasonable utilization and the principle of no significant harm; this is resolved by giving priority to the former principle while giving the latter special status. ${ }^{117}$

\subsection{The Obligation to Cooperate}

The duty to cooperate is generally accepted as customary international law and is reflected in several regional and international instruments. ${ }^{118}$ The duty of notification is also an autonomous requirement of customary international law (and usually of conventional arrangements) and is equally central to an effective implementation of both the principle of equitable and reasonable utilization and the duty to prevent significant transboundary harm. ${ }^{119}$ The duty is articulated in Article 8 UNWC and, as a result, watercourse states are obliged to cooperate on the basis of sovereign equality, territorial integrity, mutual benefit and good faith in order to attain optimal utilization and adequate protection of an international watercourse. Arguably, implementation of the substantive obligations without clear respect for the procedural obligations would be otiose. Similarly, Article 4 of the ILC Draft Articles on the Prevention of Transboundary Harm requires the states concerned to cooperate in good faith in preventing significant transboundary harm or minimizing the risk thereof.

Generally, states have a duty to cooperate over the utilization and management of shared watercourses, but the legal implications of this duty remain somewhat ambiguous. The cooperation principle by definition is an abstract rule and the specific obligations of states concerned should be clearly expressed. ${ }^{120}$ According to Article 9 UNWC, watercourse states are further obliged to regularly exchange data and information on the condition of the watercourse. This could be considered one of the specific obligations of states under the general obligation to cooperate. Thus, the obligation to cooperate could be treated as a general framework under which several other specific obligations should be fulfilled by the states concerned. These specific obligations, as they are set out in Part III UNWC in respect of planned measures, clearly fit within the general duty to cooperate. Indeed, according to Part III, states are obliged to exchange information and consult each other and, if necessary, negotiate on the planned measures which may have a significant adverse effect on other watercourse states. Sophisticated notification, consultation and negotiation arrangements are provided in Part III, and states are required to comply with these arrangements. However, Article 24 UNWC requires watercourse states to enter into consultations concerning the management of the international watercourse, at the request of any of them. 'Management' is defined in Article 24 as: (a) planning the sustainable development of

\footnotetext{
117 A. Rieu-Clarke, R. Moynihan and B.-O. Magsig, UN Watercourses Convention User's Guide (IHP-HELP Centre for Water Law, Policy and Sciences (under the auspices of UNESCO), 2012).

118 C. Leb, Co-operation in the Law of Transboundary Water Resources, Vol. 102 (Cambridge University Press, 2013), pp. 80-2.

119 Chiussi, n. 73 above, p. 253.

120 McCaffrey, n. 116 above, p. 470.
} 
an international watercourse and providing for the implementation of any plans adopted; and (b) otherwise promoting the rational and optimal utilization, protection, and control of the watercourse. Hence, it seems that such consultation is wider than that concerning planned measures and includes a wider scope, such as the establishment of a joint management mechanism for utilization of the shared watercourse.

A similar but broader approach is adopted in the ILC Draft Articles on the Prevention of Transboundary Harm. Article 6 holds that the state of origin should require prior authorization for any activity carried out in its territory, or otherwise under its jurisdiction or control, which may lead to significant transboundary harm. Further, Article 7 requires the state of origin to assess the possible transboundary harm caused by that activity via an environmental impact assessment (EIA). Article 9 requires the state of origin to provide states likely to be affected with timely notification of the assessment and all available technical and other relevant information on which the assessment is based. Further, at the request of any of the states concerned, in order to prevent significant transboundary harm they should engage in consultation within a reasonable time frame. Interestingly, in Article 9(2) the ILC suggests that the objective is to reach an equitable balance of interests, as it confirms that states should employ 'best efforts' to comply with information requests from other watercourse states, but may condition compliance upon payment of reasonable costs. Article 10 further determines the factors related to an equitable balance of interests.

The ILC Draft Articles require of the state of origin a regular exchange of information while the activity is being carried out, and provision of information to the public likely to be affected by an activity within the scope of the Draft Articles. Interestingly, the ILC expects the state of origin to take into account the interests of a state likely to be affected, even if consultation failed to produce an agreed solution. Obligations such as conducting a (transboundary) EIA are necessary to ensure a meaningful implementation of the duty to notify other watercourse states of planned measures likely to affect them. Such an EIA forms the basis for follow-on obligations which might prove necessary, including duties to consult and negotiate in good faith. Therefore, the development in international law requires a state of origin to conduct an EIA which considers the interests of states likely to be affected. This is reflected in the 2010 judgment of the ICJ in Pulp Mills as customary international law. ${ }^{121}$ Hence, there is no doubt that conducting an EIA which considers the interests of the state likely to be affected and its local community is a specific obligation required by international law.

Accordingly, the effective implementation of both the equitable and reasonable utilization principle and the no-harm principle are heavily reliant upon procedural requirements. Thus, procedural principles, which relate to the general obligation of states to cooperate, not only serve as a basis for avoiding disputes and strengthening cooperation over international watercourses, but also support the substantive principles.

121 See S. Marsden, Transboundary Environmental Governance: Inland, Coastal and Marine Perspectives (Routledge, 2016), p. 281. 


\subsection{Other Legal Sources}

This brief overview of the state of customary international law related to dam construction in a shared watercourse shows clearly that when a state has the intention to build such a dam which may have negative impacts on the quantity of water to be received by the downstream state(s), the state of origin is required to meet various obligations which are part of the corpus of international law and are binding upon all states. Putting international water law obligations aside, such international obligations could be further analyzed from three perspectives: (i) international environmental law, (ii) human rights, and (iii) equity concerns. Environmental legal instruments, such as the Ramsar Convention, ${ }^{122}$ require parties to implement their planning to promote the conservation of wetlands and, as far as possible, the wise use of wetlands in their territory. Therefore, riparian states could also be obliged to take specific action to protect the ecosystem of a shared watercourse. In such cases, riparian states should inform other riparian states or organizations if the ecological character of the shared watercourse is changing or is likely to change as a result of technological developments. Moreover, other sources of international environmental law, such as the $1992 \mathrm{CBD},{ }^{123}$ could be significant in the assessment of transboundary water damage. The assessment does not merely relate to the damage caused by inequitable water use per se, but extends to broader secondary impacts concerning environmental issues, which are also covered in the Stockholm Declaration ${ }^{124}$ and the Rio Declaration.

The construction of a dam in an international watercourse has the potential also to have a negative effect on human rights. ${ }^{125}$ It could lead to the displacement of particular (often vulnerable) groups. Without adequately considering the interests of indigenous people, such a development may also endanger indigenous water rights. ${ }^{126}$ Construction by an upstream state also frequently takes place to guarantee drinking water for its population, but may at the same time reduce the water supply for downstream users. Arguably, any utilization of a shared watercourse which restricts access to fresh water from that watercourse is inequitable. Therefore, the right to water should be respected, irrespective of the position of the state involved, in proportion to the actual needs of riparian states. ${ }^{127}$ This equally raises the question of how dam construction relates to the fundamental right to water. Both the international community and authoritative human rights bodies increasingly recognize a human right to water. Under Articles 11 and 12 of the 1966 International Covenant on Economic, Social

122 N. 61 above.

123 N. 62 above.

124 On the 1972 Stockholm UN Conference on the Human Environment see Sands \& Peel, n. 76 above, pp. 30-2.

125 On the relationship between environmental protection and human rights see Sands \& Peel, n. 76 above, pp. 777-80.

126 M. Finn \& S. Jackson, 'Protecting Indigenous Values in Water Management: A Challenge to Conventional Environmental Flow Assessments' (2011) 14(8) Ecosystems, pp. 1232-48.

127 T.S. Bulto, The Extraterritorial Application of the Human Right to Water in Africa (Cambridge University Press, 2014), p. 194. 
and Cultural Rights (ICESCR) ${ }^{128}$ the right to water is legally binding. ${ }^{129}$ General Comment 15 - adopted in 2002 by the UN Committee on Economic, Social and Cultural Rights, which monitors the implementation of the ICESCR - provides that 'the human right to water is indispensable for leading a life in human dignity. It is a prerequisite for the realization of other human rights'. All three riparian states of the Harirud Basin have ratified and acceded to the ICESCR, yet this provision is not applied to individuals outside the territory as the states in question have not voted on the Optional Protocol to the ICESCR.

Ultimately, the concept of 'equity' and its applicability in international law have received scattered support through state practice and international tribunal awards. ${ }^{130}$ Equity could have three functions in the context of transboundary shared watercourses: (i) to assess the equitable share of riparian states; (ii) to ensure that all relevant circumstances and stakeholders are taken into consideration; and (iii) to determine the governing law and its application. ${ }^{131}$ As discussed in Section 3.4, in its normative function shared water utilization will have the capacity to meet the needs of equity. Nevertheless, as McIntyre argues, the formulation of the equitable and reasonable utilization principle does not provide guidance for the true realization of an equitable outcome. $^{132}$ Therefore, it is necessary to invoke other principles such as that of common but differentiated responsibility of states. ${ }^{133}$ It is not possible within the limited scope of this article to further develop those other aspects. It is, however, important to recognize that the assessment of the legitimacy of dam construction necessarily involves more than merely an analysis of international water law.

\subsection{Summary}

Assessing the legitimacy of dam construction according to international law requires the incorporation of a wide variety of factors. Focusing exclusively on international water law, it can be held that the legitimacy of such construction depends not only on states' compliance with substantive norms such as equitable utilization and the no-harm principle, but equally on their procedural duty to cooperate, as well as the duty to notify. More particularly, the latter obligation is of crucial importance as it can facilitate a culture of communication among co-riparian states by providing a shared language, common understandings and several starting points for structured interstate discussions. Moreover, since the adoption of the UNWC, the concept of

128 New York, NY (US), 16 Dec. 1966, in force 3 Jan. 1976, available at: http://www.ohchr.org/EN/ ProfessionalInterest/Pages/CESCR.aspx.

129 See I. Biglino \& C. Golay, The Optional Protocol to the International Covenant on Economic, Social and Cultural Rights, Academy In-Brief No. 2, (Geneva Academy of International Humanitarian Law and Human Rights, 2013).

130 McIntyre, n. 91 above.

131 R. Higgins, Problems and Process: International law and How We Use It (Clarendon Press, 1994), p. 220 .

132 McIntyre, n. 91 above.

133 T. Deleuil, 'The Common But Differentiated Responsibilities Principle: Changes in Continuity after the Durban Conference of the Parties' (2012) 21(3) Review of European Community \& International Environmental Law, pp. 271-81. 
integrated water resources management has been developed, which implies the necessity to address the legitimacy of dam construction not merely by focusing simply on one dam (the Salma Dam), but by looking at water management in an integrated manner (in this instance, for example, looking equally at the impacts of the Doosti Dam). A final assessment of legitimacy might even go beyond water and environmental law to include an analysis of human rights aspects and equity considerations. Thus, a holistic analysis of the legitimacy of dam construction entails a complicated exercise that includes all relevant dimensions in the river basin in question.

Before proceeding to such a legitimacy assessment, the next section considers the probable impacts caused by the construction of the Salma Dam. This analysis will facilitate an examination of whether, in building the Salma Dam, Afghanistan has complied with its international obligations.

\section{PROBABLE IMPACTS CAUSED BY THE CONSTRUCTION OF THE SALMA DAM}

\subsection{Flow Regime in Different Possible Conditions (Cases)}

Iran and Turkmenistan jointly built the Doosti Dam in 2004. On the other side, Afghanistan opened the Salma Dam in 2016. The focus of this part of the study is the assessment of the probable impacts of the Salma Dam (located in the upper reaches of the Harirud Basin) on the downstream area. As no impacts of the Salma Dam have yet been reported, it should be noted that these impacts are assessed based on a simulation in a technical model. The following simulations are based on potential impacts of the dam in the near future. This section will first discuss those impacts while Section 5 will assess those negative consequences in light of relevant international law principles.

Using the Water Evaluation and Planning System (WEAP) technical model, ${ }^{134}$ along with available data covering the past 43 years, it is possible to take into account various demand priorities and supply preferences and to simulate various possible case scenarios. These simulations relate to water supply and demand, based on socio-economic developments and hydrological changes in the basin. They have been modelled based on certain assumptions, such as what the situation would be in a case of there being no dams in the basin (Case 1 under normal hydrological conditions), or in a case where both the Salma Dam and Doosti Dam are operational (Case 2 in normal hydrological conditions). Cases 3 and 4 are the same as Case 2 with the addition of experiencing severe conditions of respectively a $25 \%$ and a $50 \%$ reduction of water flow in the dry season. ${ }^{135}$ It is important to note that, technically, it usually takes time until

134 A large number of studies use the WEAP system to develop a water resources planning tool for transboundary and international river basins: see, e.g., H. Hoff et al., 'A Water Resources Planning Tool for the Jordan River Basin' (2011) 3(3) Water, pp. 718-36; J.C. White, T.W. Tanton \& D.W. Rycroft, 'The Impact of Climate Change on the Water Resources of the Amu Darya Basin in Central Asia’ (2014) 28(15) Water Resources Management, pp. 5267-81.

135 This means that the inflow of the river in normal hydrological conditions will reduce by $25 \%$ and $50 \%$ as a result of a possible natural decline in precipitation. 
the actual impacts of a dam construction are observed in the downstream. Therefore, since no data is available regarding the actual impacts of the Salma Dam on the flow regime of the downstream area at this time, this study relies on the WEAP to simulate probable impacts.

The results of the WEAP simulation reveal the negative future impacts of the construction of the Salma Dam in Afghanistan on the water flow regime downstream, in Iran and Turkmenistan. It is expected that the discharge of water downstream will be reduced by approximately $30 \%$ to $80 \%$ in different scenarios. In addition, ecological conditions in the downstream area of the Salma and Doosti Dams, particularly in Turkmenistan, are forecast to be severely damaged by the development of the dam in the upstream area.

\subsection{Impacts of the Dams on the Water Flow Regime}

Considering the above assumptions, Table 3 shows the annual inflow that is simulated and predicted to have reached the Iranian border in the various assumed cases in the last 10 years of the time period as a result of the construction of the Salma Dam.

Table 3 shows that the construction of the Salma Dam in Afghanistan is likely to reduce the average annual flow in Case 2 in comparison with Case 1 (a 30\% reduction compared with when the Salma Dam is not operated). The impact is much worse in Cases 3 and 4 during possible dry climatic conditions (around 70\%-80\%). In addition, the maximum annual inflow is forecast to decline from 3,137.42 MCM (Case 1 - without the Salma Dam) to 2,719.40 MCM (Case 2 - with the Salma Dam). The results also show that the number of years in which the annual flow falls below $51.59 \mathrm{MCM}$ (which is the actual minimum annual flow in the natural case) and $200 \mathrm{MCM}$ (which is the required minimum annual environmental flow) is predicted to increase dramatically in Cases 2, 3 and 4. The detailed results in Case 2 also forecast that the irrigation water for use in Iran and Turkmenistan reduces by $34 \%$ (which means that it limits the irrigation lands) in comparison with Case 1. Moreover, ecological water use is also predicted to be severely reduced by the development of the dam in the upstream area, either in Afghanistan or in IranTurkmenistan. The model demonstrates that the environmental flow will decrease by $50 \%$ in Case $2 .{ }^{136}$

Figure 2 illustrates the variation in water storage of the Doosti Dam, with and without the Salma Dam, over a 43-year period (the period for which data is available). The water storage of the Doosti Dam is expected to be reduced to zero 15 times in 43 years after the construction of the Salma Dam, while it would be only 5 times out of 43 years in the case 'without the Salma Dam'. ${ }^{137}$ All these negative effects on water quantity in the downstream part of the basin as a result the construction of the Salma Dam may cause severe secondary impacts, targeting human vital needs - namely, drinking

136 For more detailed information, see Nagheeby, n. 20 above.

137 Ibid. 
Table 3 Annual Inflow at the Iranian Border under Different Assumed Cases

\begin{tabular}{|c|c|c|c|c|c|}
\hline Case & $\begin{array}{c}\text { Minimum } \\
\text { annual } \\
\text { inflow } \\
\text { (MCM) }\end{array}$ & $\begin{array}{l}\text { Average } \\
\text { annual } \\
\text { inflow } \\
\text { (MCM) }\end{array}$ & $\begin{array}{c}\text { Maximum } \\
\text { annual } \\
\text { inflow } \\
(\mathrm{MCM})\end{array}$ & $\begin{array}{c}\text { No. of years (o/o 43) } \\
\text { in which annual } \\
\text { inflow }<51.59 \mathrm{MCM} \\
\text { (minimum annual } \\
\text { flow) }\end{array}$ & $\begin{array}{l}\text { No. of years }(\mathrm{o} / \mathrm{o} 43) \text { in } \\
\text { which annual inflow } \\
<200 \text { MCM (minimum } \\
\text { annual environmental } \\
\text { flow) }\end{array}$ \\
\hline 1 (Natural) & 51.59 & $1,018.63$ & $3,137.42$ & 0 & 4 \\
\hline 2 (Both) & 18.64 & 761.75 & $2,719.40$ & 4 & 10 \\
\hline $3($ Both $+25 \%)$ & 13.98 & 492.30 & $1,532.90$ & 4 & 15 \\
\hline $4($ Both $+50 \%)$ & 9.32 & 235.42 & 981.10 & 7 & 24 \\
\hline
\end{tabular}

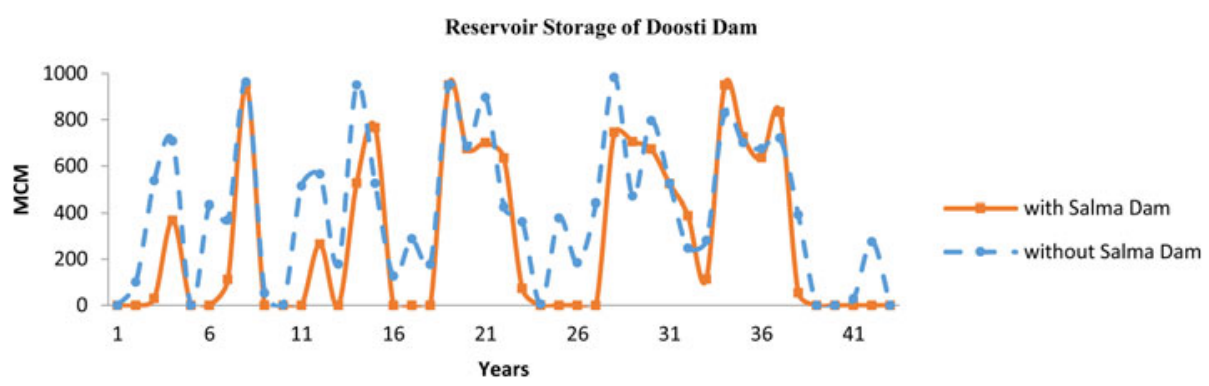

Figure 2 Water Storage of the Doosti Dam in the Case of 'With Salma Dam' and 'Without Salma Dam'

water, loss of livelihoods (particularly in the agricultural sector), displacing the local downstream residents, and destroying the ecosystem.

\section{EVALUATING THE LEGITIMACY OF THE CONSTRUCTION OF THE SALMA DAM}

As a starting point we mentioned that limited sovereignty gives Afghanistan the basic right to utilize the shared watercourse and develop a dam on the Harirud River. At the same time, Afghanistan is obliged to comply with its international obligations. The legitimacy of the behaviour of Afghanistan can firstly be analyzed from the perspective of whether it has complied with its legal obligations under international water law. Secondly, as legitimacy goes beyond merely assessing compliance with international water law, some other aspects, such as equity and the right to development, will also have to be considered.

\subsection{Afghanistan's Utilization of the Harirud Water}

The central question for discussion is whether the way in which Afghanistan exercised its right can be considered as complying with its obligations under international law. Neither of the riparian states to the Harirud River is a member of the UNWC. However, the equitable and reasonable utilization principle forms part of customary 
law and is therefore binding upon all states, including Afghanistan. The modelled substantial damage and negative impacts resulting from the building of the Salma Dam show that the shared watercourse is not being utilized in a manner that can be considered equitable and reasonable. In order to utilize a shared watercourse in an equitable and reasonable manner, all relevant factors as listed in Article 6 UNWC should be analyzed diligently by taking into account the interests of other riparian states. By operating the Salma Dam, Afghanistan uses a substantially larger proportion of the water resources - as is illustrated in Table 3 and Figure 2 - than what could be considered an equitable and reasonable share according to the criteria provided in the UNWC. By not assessing the interests of other riparian states and by not allocating to them an equitable and reasonable share of the Harirud River, Afghanistan has not respected the principle of equitable and reasonable utilization.

\subsection{The Construction of the Salma Dam under the No-Harm Principle}

The construction of the Salma Dam has had a severe impact on downstream states. This damage has occurred as a result of building a hydro-electric power installation with a plan to expand the irrigation area on a shared river. Such an act could be conducted only under the control or with the permission of the state of origin. Finally, the consequences are suffered by the downstream countries. These consequences could be summarized as negative impacts on securing water for vital human needs, on the agricultural population (through involuntary displacement and resettlement), and environmental degradation, particularly in the Karakum desert.

Therefore, given the significant transboundary damage resulting from the construction of the dam, it seems that Afghanistan has not complied with the no-harm obligation either.

\subsection{The Obligation of Afghanistan to Cooperate}

In addition, Afghanistan did not respond to the messages or notifications from downstream countries to cooperate. It is submitted that the procedural obligations of shared watercourse states require that, in order to comply with their substantive international obligations, they should cooperate in an exchange of data and information to conduct assessments and, if necessary, engage in consultation and negotiation. Indeed, any watercourse state must cooperate with other co-riparian states in determining an equitable allocation of water, taking into account the equitable and reasonable utilization principle. This means that, in order to determine equitable and reasonable utilization, watercourse states may consider the establishment of joint mechanisms or notify the results of their assessment to other potentially affected states to enable them also to evaluate such utilization. In the event that the state of origin does not establish such a joint assessment or does not notify other potentially affected states, it could be argued that this state has failed to comply with its obligation to cooperate. ${ }^{138}$ In such circumstances, other watercourse states may argue that the utilization of the shared watercourse is inequitable and

138 See further the Pulp Mills case, n. 83 above. 
unreasonable. At a minimum, they can argue that an assessment, if any, was conducted without adequate consideration of the interests of other affected watercourse states. As mentioned above, one of the implications of the duty of notification is the obligation to conduct a (transboundary) EIA, which could have enabled consideration of the potential impact of the project on other watercourse states. Afghanistan, as the state of origin, has neither consulted with potentially affected states (Iran and Turkmenistan), nor shared the results of any assessments it would have conducted. This obligation therefore seems to have been violated by Afghanistan.

\subsection{Equity and Other Considerations}

It is one thing to establish that an upstream state (Afghanistan in this case) would have violated obligations under international law as it uses the shared water in an inequitable and unreasonable manner, and as it violates the no-harm principle and the duty to cooperate. It is yet another to conclude that its behaviour in building the Salma Dam is illegitimate overall, as this could require a broader analysis, such as equally including human rights or equity considerations. It is not immediately clear to which results the incorporation of those considerations would lead. A distinction should be made between the upstream state's compliance with its international obligations and its right to build a dam on a shared watercourse.

The construction of the Salma Dam may have negative impacts on downstream states. Such impacts may lead to a wide range of problems for downstream states, including but not limited to a shortage of drinking water and environmentally adverse impacts. Therefore, the construction of the Salma Dam will undoubtedly result in substantial damage to downstream states. Nonetheless, not all types of impact could be considered to be compensable damage under international law. Furthermore, as an upstream state, Afghanistan may invoke its right to water and justify its utilization of the Harirud River. In sum, the negative impacts of the construction of the Salma Dam are complex to measure, but the occurrence of such impacts is unavoidable. Nevertheless, one may argue that the upstream state - which, in this scenario, has a lower development index than the other riparian states and concurrently suffers from severe poverty and lack of infrastructure, even for drinking water, as a result of a protracted civil war - will have the right of an equitable and reasonable utilization of the shared river. No one can preclude such a sovereign state from utilizing its natural resources in accordance with international law.

The technical story aspects of the construction of the Salma Dam reveal a dilemma which arises with many dam-related projects. On the one hand, an upstream state has the right to use its water resources for its economic development and for the benefit of its own citizens; on the other hand, the construction of the dam may lead to negative impacts on the downstream states. The contribution of international law is, of course, precisely to facilitate a reconciliation between these two competing interests. In legal terms, this leads to the question of whether the negative impacts resulting from the construction of the dam are such that one can no longer argue that there is a lawful utilization of the water resources by Afghanistan. 
As a country with the lowest development index, Afghanistan claims that a development project such as the Salma Dam is necessary to overcome poverty. The country was involved in several armed conflicts for years and, as a result, its infrastructure and irrigation systems, in particular, were either destroyed or not developed. Therefore, the development of water resources for Afghans - such as the Salma Dam in the Harirud River - is defined as a key policy to alleviate the existing vulnerable socio-economic conditions. ${ }^{139}$ However, the socio-economic needs of the downstream countries are also highly dependent upon the shared waters of the Harirud River. Developing a hydro-electric project in one of the least developed countries without considering the interests of downstream countries may increase regional rivalries. This dichotomy may lead to an approach discussed by McIntyre, which suggests that there should be a proportionate distribution of benefits in the use of a shared resource. ${ }^{140}$ This maxim could be used to ensure a proportional balancing of the legitimate interests of the Harirud watercourse states. To develop this approach, their current circumstances, development level, economic capacity and needs should be taken into consideration.

In sum, the fact that Afghanistan is a least developed country may give it a stronger claim to use the Harirud River as a development goal and to protect the right of its citizens to drinking water. Yet, it is not clear to what extent these equitable and human rights considerations would necessarily have to be considered more important than the negative consequences to which the dam construction would lead in the downstream states. After all, its construction could also lead to violations of human rights for downstream users - for example, in the case of forced displacement of local populations because of a changed watercourse, or in the case of a violation of the right to water in downstream states. In sum, equitable treatment and human rights considerations are undoubtedly of importance, but do not necessarily lead to a clear-cut outcome when assessing the legitimacy of dam construction.

\subsection{Implications}

From the above analysis it seems that, given the negative consequences of the construction of the dam on the downstream users, Afghanistan may have violated its substantive obligations under international law. More particularly, the principle of equitable use and the no-harm principle may have been breached. Perhaps of more importance (and less debatable) is the fact that Afghanistan has violated the obligation to cooperate and the duty of notification. The entire ethos of the international water regime is precisely to create a culture of communication among co-riparian states, which could have been possible if the duty of notification had been respected. Evidently, the most important policy implication is not that a violation of its obligations would result in Afghanistan no longer being able to make use of the dam. After all, the essence of the equitable and reasonable utilization principle is precisely that riparian states need to agree on the amount of the particular water source that each could use. The most

139 O. Joya, Natural Resources: What Strategy for Afghanistan? (Samuel Hall, 2012).

140 See McIntyre, n. 97 above. 
important conclusion, therefore, is that what should happen now is what should have happened earlier: negotiations leading to, preferably, a joint management of the entire river basin and, potentially, an adjustment to the share of water used in order to reach an equitable and reasonable utilization of the water. In this respect, the role of international organizations like the $\mathrm{ADB}$, the World Bank, and outside-basin states like India is important and must comply with international law.

\section{CONCLUSION}

The goal of this contribution was to explore how the concept of legitimacy within the context of international water law can be applied to the specific case of building the Salma Dam. In using the Harirud River basin as the setting, this article focuses on the UNWC, which establishes normative standards that enable an assessment of the legitimacy of dam construction in an international water course.

We have argued that building the Salma Dam in Afghanistan may have dramatic impacts on the downstream states, Iran and Turkmenistan. Such an impact would not be limited to environmental damage, but may also lead to large-scale displacement of local communities, who need drinking water, and to the destruction of their livelihood. This may result in environmental damage and economic loss, as well as a disregard for human rights to adequate food, water, and shelter. Such damage could be limited through an equitable and reasonable utilization of the shared watercourse in question. In that case, all watercourse states, including upstream and downstream states, will have the right to utilize the shared watercourse. Nevertheless, such utilization must comply with international law. Although various theories have been introduced in international law in relation to the management and utilization of a shared watercourse, the equitable and reasonable utilization principle is widely accepted as a customary rule of international law and therefore is binding upon all states. As a result, the watercourse states have a customary legal obligation to utilize the shared watercourse in an equitable and reasonable manner and not to cause significant transboundary damage to other watercourse states. These obligations are accompanied by the procedural obligation to cooperate and to conduct a transboundary EIA of projects before permitting them.

In the particular case of the Salma Dam, Afghanistan as state of origin has failed to comply with its international obligations regarding the adequate assessment of the impacts of the project and the exchange of information concerning the development of the dam. Furthermore, our analysis has shown that operating the Salma Dam at full capacity will cause significant transboundary damage to downstream states. Therefore, we conclude that in building the Salma Dam on the Harirud River, the state of origin failed to comply with its international obligations. We used the broader notion of legitimacy to assess the construction of the dam, arguing that obligations other than those resulting from international water law (such as environmental law and human rights), as well as equity considerations, would also have to be incorporated in the assessment. However, applying those considerations in practice does not lead to clear-cut results. 
The most important conclusion is that the concept of equitable and reasonable water use also enables parties in principle to search for constructive options, leading to an optimal utilization of the shared water resource. Given Afghanistan's non-compliance with its duty of notification, it has been impossible to establish a culture of open communication between the three co-riparian states to date. It is hoped that clarifying the obligations under international water law and assessing the broader legitimacy of the construction of the dam may enable the riparian states to institutionalize mutual cooperation and create a functional mechanism of benefit sharing for the entire river basin, thus respecting the interests of all co-riparian states involved. 